is absorbed, leaving insecticide particles freely exposed. On all types of surface, toxicity is inversely related to size of particle, because smaller particles are more easily picked up and retained by insects.

Dr. Barlow then dealt with factors affecting the persistence of deposits on various types of surface. Volatile insecticides exhibit decreasing residual action for a range of substrates from non-absorbent to absorbent. Increasing rates of evaporation and sorption into the substrate are responsible. Loss of insecticide has been found to be extremely rapid on certain adsorptive substrates and is due almost entirely to sorption; for example, on mud-blocks prepared from lateritic earths used for hut-building in several tropical countries.

Insecticides possessing fumigant action, for example, BHC and 'Aldrin', are effective for long periods after sorption, but others are ineffective after sorption, for example, DDT and 'Dieldrin'.

Finally, Dr. Barlow considered residual deposits of oil solutions. These deposits can be employed on non-absorbent surfaces, when formulations which do not crystallize are to be preferred because the recumbent crystals produced on such surfaces are not readily picked up by insects. By way of contrast, on fibrous absorbent surfaces, oil solutions are not available at first ; but after crystallization has occurred the crystals project from the superficial fibres and are readily detached by insects.

Opening the discussion, Dr. A. B. P. Page observed that all three speakers had dealt with ratedetermining processes. While there are big differences between fumigation and contact action, in each process accumulation and penetration of the toxicant are continuously occurring alongside toxification and detoxification within the insect. With fumigants, one measure of toxicity is the product of the concentration of the fumigant multiplied by the period of fumigation. In the same way the toxicity of a contact poison may be expected to be some integral function of the net amount of toxicant on the insect and the period of contact.

In certain fumigations a better measure of toxicity appears to be the amount of fumigant sorbed by the insects, and this relation implies dependence of toxicity on the shape of the concentration-time curve as well as on the area under it. An analogous relation may be found for contact poisons where large amounts of insecticide accumulated initially by the insect may greatly influence toxicity despite their rapid removal by cleaning movements.

Dr. Page remarked that Dr. McIntosh had concerned himself with the solubility of poisons in the epicuticular wax layer, but had not mentioned the possibility of preferred sites of diffusion through the cuticle and access to specific sites of action. Such considerations are important. Referring to Dr. Barlow's account of the fumigant action of certain solid insecticides absorbed into porous substrates, he recalled an analogous case of absorption in bagged stored products treated with an insecticidal dust; wheat, for example, can absorb enough $\mathrm{DD}^{\prime} \mathrm{T}$ in the seed coats to enable the insecticide to act as a contact and stomach poison, whereas with BHC the fumigant action is all-important.

In reply to a question from Dr. J. R. Booer, Dr. McIntosh said that his colloidal suspensions were prepared in a standard way but he had not measured the size of particle.

Dr. J. C. McGowan pointed out that Ferguson's theory cannot be related to the system described by
Dr. McIntosh. If insects are treated with aqueous solutions of insecticide, then the theory can be used; but the solubility of DDT in water is so low that a lethal dose cannot be applied by such a method. Mr. G. F. H. Whitney observed that Ferguson's theory applies to substances showing 'physical' toxicity; a substance showing a toxicity greater than that expected by the application of Ferguson's theory invokes 'chemical' toxicity. Dr. McIntosh commented that he had not stated that Ferguson's theory is valueless, but that it is not useful in the case of DDT and its analogues. In answer to Mr. P. S. Hewlett, he agreed that he considers the action of DDT to be physical.

Mr. F. H. Rae asked whether Dr. Barlow advocated whitewashing huts before spraying, which he considered would not be a practicable procedure. Was sodium silicate useful and could Dr. Barlow suggest any other substance which might reduce losses due to sorption? Dr. Barlow said that the ideal would be to incorporate a substance in the spray which would block the capillary spaces in the substrate and thus reduce sorption. Size is not suitable for tropical use. The problem is being studied; but he had no practical recommendations to make at present.

Mr. P. Bracey asked if it is known whether BHC in the vapour phase enters an insect through the integument or through the spiracles; Dr. Page thought that no information is available.

Closing the discussion, Mr. W. H. Read stressed the practical importance of work in this field.

\section{THE PLACE OF UNIVERSITY GRADUATES IN INDUSTRY}

$T$ WO most interesting points are featured in the report of the Universities and Industry Conference, organized by the Federation of British Industries and by the Committee of Vice-Chancellors and Principals of the Universities of the United Kingdom, and held at Ashorne Hill daring October $24-26,1952^{*}$ : the first is the further support which is forthcoming for the argument advanced in the last report from the Advisory Council for Scientific Policy that a new attitude towards industry and technology is desirable on the part of the schools and the universities; and the second is the large measure of agreement in addresses and discussions to the effect that, in consequence of the large proportion of talent which is now entering the universities, industry must necessarily rely to a much greater extent on recruitment from the universities to provide its future leaders (its chances of recruiting the requisite ability from those leaving school direct has been greatly diminished). The published report contains the addresses by the following : Sir John Maud on the use of the university graduate in the Civil Service and the qualities of the graduate which have proved most useful ; Sir Ewart Smith on the qualities industry requires in the university graduate and his role in industry; Dr. Eric Ashby on the ability of the universities, consistently with their other obligations, to turn out men with the qualities required by industry; and

* Report of the Universities and Industry Conference, organized by the Federation of British Industries and the Committee of ViceChancellors and Principals of the Universities of the United Kingdom, Pp. 87. (London: F.B.I., 1953.) 58. 
Mr. A. D. Bonham-Carter, Mr. Ralph Colman and Mr. A. (x. Grant on industry's use of the university graduate. Also included are Sir Robert Wood's reflexions on the conference at its final session, and a summary of the main points which emerged, by Sir Norman Kipping, Dr. C. R. Morris and Mr. D. R. O. Thomas.

Sir John Maud, in a very frank and stimulating address, made it clear that the Civil Service is looking for essentially the same qualities of integrity, courage, readiness to work, straight and original thinking and the capacity to make up one's mind as is sought by industry; nevertheless, he thought, while the Civil Service requires a larger proportion of first-class graduates than it has been receiving, it is of importance to the national interest that, during the next ten years at any rate, the claims of industry for first-rate men should receive priority. It is a matter of national importance that the university graduate should come to regard industry and commerce not merely as careers which offer a reasonable chance of a livelihood and of satisfying ambitions but also as opportunities of doing something in the nature of service in which they can take pride. Sir John earlier in his address had commented pointedly on some of the objectionable qualities to be found in the university graduato-qualities such as bad manners, inaudibility, and excessive specialization, which are not by any means limited to those who elect to enter the Civil Sorvice.

Sir Ewart Smith likewise referred to the importance of influencing the general climate of opinion with rogard to industry. He thought that wider recognition of the teaching of administrative studies in the universities would help to this end as well as to improve the quality of future management, but the idea that management should be taught in the universities found little support from him or other industrial representatives present, apart from $\mathrm{Mr}$. N. G. MeCulloch. The idea that management is a technology or a fit subject for university teaching was rejected forthright by Mr. A. G. Grant and Dr. Ashby, and Sir Ewart clearly voiced the general opinion of industrial representatives in his view that the first requirement is for men and women who have been trained to think, to understand, to be critical and to show initiative, and who have some understanding of wider aspects of life than can be gathered from one particular discipline. He thought that this wide outlook and capacity to think can be acquired through technology or science, as well as through the arts, if the subjects are properly taught, and at present, as Prof. J. A. L. Matheson reminded the Conference, the technological departments are not getting their fair share of first-class brains.

Dr. Ashby's address supplied the quantitative basis for the argument that industry must rely increasingly on the universities for its recruits for management. While, since 1912, the reservoir of persons eighteen years old has decreased by 74,000 , the number from the reservoir who have entered universities has increased by 12,537 , and during 1951 73 per cent of university students were receiving financial aid, mostly from public funds. The barrier to university education is now largely intellectual, not financial, and it is becoming difficult for a reasonably bright boy who remains at school to avoid going to a university. Already the universities are taking as much as a third or more of the educated high talent in the reservoir and may well take more as the machinery for separation becomes more efficient.
This position makes it essential, continued Dr. Ashby, that the universities should discover the needs of industry; but he urged that industry should itself do much more to make known both its needs and its opportunities and to further a better understanding of the true purpose of industry, of its vital importance to the nation, and of the interest and satisfaction that it can offer to those who serve in its higher ranks.

'That industry should do much more to explain its nature and purpose to the nation, and to persuade potential entrants that it provides a purposeful career with manifold opportunities for using good brains in essential work, was a main point which emerged at the Conference. This task should begin with the schools and the universities by publishing well-written literature designed to stimulate the imagination of young persons. The proportion of the ablest grammar-school boys who go to the universities has continued to increase, but the increase in the university population has not led to a corresponding increase in the number of men obtaining first-class honours degrees. Accordingly, even if industry were to recruit its due proportion of high ability of this kind, it might still fall short of its requirements, since the nation's total needs must be met from this strictly limited supply. This necessitates the fullest use being made of those with high ability wherever they are employed, and opinion was expressed that noither industry nor the Civil Service is yet making the best use of the specialist graduates it recruits.

Much remains to be done to broaden the education of the university graduate, and it is as clear from this conference as from the regional conference at Nottingham during the previous month that industry is critical of excessive specialization in first-degree courses and looks, above all, for those qualities on which Sir John Maud and Sir Ewart Smith laid emphasis. There is no evidence of a desire to stipulate a particular content of university education or, as already noted, to advocate the teaching of administrative studies at the undergraduate level. The universities would make their most effective contribution in the broader educational field by helping industry to continue the education and training of the graduates and men of equal ability it recruits. Reference was made to several experimental courses designed jointly by industry and the universities for men of this type who have been several years in industry and are twenty-five to thirty years of age. It was also noted that there has been no great industrial support for the postgraduate courses in technology which the universities have organized in response to a request made by industrialists at the conference held in 1949.

One further point needs to be emphasized by industry in its approach to the schools and universities regarding careers in industry. Although industry requires more men of high ability, the opportunities it can offer graduates are not unlimited. For most technical industries it is estimated that 4 per cont of the total employees fill scientific, administrative and management posts for which a graduate could appropriately compete. Only a few graduates could hope to reach the highest positions; but industry requires many more good men for the tasks of middle management, and these offer a full and interesting life. In this connexion the three papers on industry's use of the graduate led to a discussion in which Prof. A. R. J. P. Ubbelohde, 
supported by others, stressed the need for more quantitative information about industrý's intake of arts or non-specialist graduates as compared with the intake of specialists of all kinds, the average industrial life of the graduate in any one firm, and the migration of specialists to non-specialist occupations in industry. Information of this kind would go far to assist in dealing with the problem presented by the arts graduate, particularly if, as suggested by Prof. H. S. Kirkcaldy, the arts graduate avoids specialization and acquires the ability to make intelligent use of experts.

\section{SARDINE FISHERY OF CALIFORNIA}

T HE fishery for sardines, Sardinops corulea, is a major industry in California; but there was a disastrous failure of the fishery during the 1947-48 season, and, although slight improvements have taken place in succeeding years, there seems at present, little hope of a major recovery before the 1954-55 season at the very earliest. The area of profitable fishing has contracted to the region of southern California, resulting in extensive land transport of fish from there to the processing plants at Monterey and San Francisco.

As an emergency remedial measure the Sardine Industry Advisory Committee introduced a temporary programme of control and management for the 1948-49 season, but this proved unsuccessful and was dropped. Resulting largely from the undiminished initiative of the industry itself, a co-ordinated programme of sardine research by five scientific bodies has been brought into being. The agencies concerned are the California Academy of Sciences, the California Department of Fish and Game, the Stanford University (Hopkins) Marine Station, the United States Fish and Wildlife Service and the University of California (Scripps) Institute of Oceanography.

A progress report covering the period January 1, 1951-June 30, 1952, has recently been published*. The picture that emerges from the work to date is not encouraging. The fish population appears to be so reduced, and the possibility of significant recruitment of young fish so small, that unless the factor of availability operates to increase the normal catch of older fish, the sardine fishery must expect for at least another two seasons the smallest catches for a generation.

Data upon eggs and larvæ, young fish, food and feeding, growth- and mortality-rates, behaviour, schooling patterns and oceanographical conditions are being collected as rapidly as conditions allowbut long-term forecasting is not yet possible.

This important programme of co-ordinated research upon a vast and baffling problem is financed in part by funds from the industry in the form of a tax on landings, in part by a grant from the Federal Government and in part by a grant from the State of California, which makes the largest contribution.

The appearance of further reports on this very ambitious programme is awaited with keen interest, for it represents one of the most intensive combined assaults upon marine biological problems that has anywhere yet been made.

* California Cooperative Sardine Research Program. Progresa Report 1 January, 1951 , to 30 June, 1952. Pp. 51. (Marine Research 1952.) n.p.

\section{OVERSEAS FOOD CORPORATION}

\section{REPORT FOR THE YEAR 1951-52}

THE annual report of the Overseas Food Corporation for the year ended March 31, 1952*, differs in form from previous reports. Throughout the year the Corporation had been engaged in implementing the terms of the White Paper issued in January 1951, involving the running down of the vast organization built up for the mechanized production of groundnuts in East Africa, and also in an attempt to establish the economics of clearing and mechanized, or partly mechanized, agriculture under tropical conditions. The Corporation is thus now engaged in a large agricultural experiment, and, apart from the chapters on policy, organization and finance, respectively, the bulk of the report deals with the agricultural experiments in the three regions; the chapter on the work of the scientific department is likewise presented on a regional basis. The run-down in the Kongwa area is described in a separate report, appended to the main report, as are the accounts for the year.

The running-down operation has been effected with marked success and without serious detriment to the agricultural work. By March 31, 1952, the Corporation had handed over to the East African Stores Disposal Board about 80 per cent of its surplus stores and equipment, while transfer of the surplus fixed capital assets was virtually complete. The reduction of the European staff by 50 per cent to 636 and of the non-European staff by 18 per cent, giving a ratio of Europeans to non-Europeans of I : 23 in place of $1: 14$, proceeded smoothly, and a high proportion of Europeans leaving the service of the Corporation found satisfactory alternative posts in East and Central Africa. The London office has been reduced to a small agency, the Nairobi agency closed, and the Dar-es-Salaam agency incorporated with the general headquarters administration, which moved to Dar-es-Salaam during November 1951. Each region is now administered by a general manager, directly responsible to the chairman in his capacity as chief executive. With the exception of the chief health adviser, who was due to leave in July 1952, the technical advisers had already left the Corporation.

Decentralization of the engineering services is complete, and decentralization of the health department was to be completed when the chief health officer left in July 1952, by which date a reduction in European staff to 38 from the 85 at March 31, 1951, was envisaged. In this final report on health services the opinion is recorded that the danger to the health of Europeans in this area was much exaggerated, and the hospital bed planning figure, originally 2 per cent of the population entitled to treatment, has been reduced to 1 per cent and is being further reduced. The most effective measure for adult mosquito control has proved to be spraying all buildings with 'Gammexane' at three-monthly intervals, and this is now compulsory in Urambo and Nachingwea. Malaria is the commonest disease affecting Europeans, and, although 'Paludrine' has not been used either as a prophylactic or for treating Africans, there is evidence of the emergence of 'Paludrine'-resistant strains of the malaria parasite.

- Overseas Food Corporation. Annual Report and Statement of Accounts for the Year ended 31st March, 1952. Pp. Iv +110. (London : H.M.S.O., 1953.) 38. 6d. net. 